\title{
Elaboration of the Importance and Necessity of Extracurricular Learning for Students who Major in Ceramic Art Design in Universities
}

\author{
Fei Yua \\ The Department of Art and Design, Jingdezhen University, Jingdezhen, Jiangxi, China
}

\begin{abstract}
The requirement for ceramic art professionals is becoming higher and higher from enterprises on the basis of the deep development of market economy. Traditional talent training mode has gradually fallen behind the requirements of the Times, and it is very important to improve students' time operation skills. It becomes necessary to carry out extracurricular learning in ceramic art major in universities. Only in the process of practice can students develop their comprehensive professional abilities. However, in view of the fact that the ability of university students themselves to obtain extra-curricular learning opportunities is relatively weak, and universities should take the initiative to reform the teaching mode, provide extracurricular learning opportunities for students, construct the teaching mode of combining work with study, in order that students can obtain enough extracurricular learning opportunities.
\end{abstract}

\section{Analysis of the importance and necessity of extracurricular learning for students who major in ceramic art design in universities}

The specialty of ceramic art has rather strong practicality and operability, pure theoretical knowledge learning can hardly meet the needs of talent training. It is accustomed to adopting teaching ways of in-class lectures and in-class experiments in the major of ceramic art in the traditional teaching mode. However, with the rapid development of market economy, and under the circumstance that enterprises are increasingly demanding for talents, it will be difficult for students to adapt to future job requirements if they only learn theoretical knowledge and their learning scope is confined within the classroom. Thus, both schools and teachers must think highly of the necessity of students' extracurricular learning. Extracurricular learning provides students with chances for project learning and comprehensive learning. They can take advantage of off-campus training opportunities provided by the school or the school-enterprise cooperation platform to carry out practical learning within enterprises, apply theoretical knowledge that has been studied to practical operation, then cultivate themselves as comprehensive and all-round talents. Students have basically understood the production process of ceramic art while they are on campus, thoroughly know production processes, such as raw material selection, grinding tool selection, slip casting, molding, decoration, burning, and color baking. What they lack is the opportunity to apply theory to practice. Teachers should encourage students to actively participate in extracurricular learning in order to make students learn of the production environment and ceramic art process of ceramic enterprises, so that students deepen their understanding of professional knowledge in the process of practice. In the process of extracurricular learning, students can observe and imitate the working process of production personnel, understand the basic laws and principles of its producing steps. In the process of participating in the production of ceramic art products, students can accumulate employability and job adaptability for future, organically integrating theory with practice. The author thinks that the school can incorporate students' extracurricular learning into its performance assessment system, guide students to participate in extracurricular learning in the form of institutionalization, making them to train themselves into talents with good professional qualities in the process of extracurricular learning.

Concerning the current situation, there exists great difficulty in extracurricular learning of students who major in ceramic art design in universities. This difficulty is mainly reflected in the following aspects:

Firstly, it is hard for students to find a platform for extracurricular learning. The best chance of extracurricular learning for students is to get an internship in a company. But enterprises are not very active in providing students with extra-curricular learning opportunities. Local governments and universities expect students to quickly enter the enterprise for internship after learning theoretical knowledge, apply it to practical operation, and make them reflect on the shortcomings of theoretical learning in practice. Many factors are thought over when enterprises accept students for extracurricular

\footnotetext{
a Feiyu:653104053@qq.com
} 
practice. If students sign employment contracts with themselves, it is to be a waste of time and energy for enterprises to train talents for other enterprises. It will also increase the cost and difficulty of enterprise management to provide students with extra-curricular learning chances, being difficult to combine with the talent pool and talent training chances of enterprises. Hence, it's not easy for students to get a chance to study after class. Universities should exert their initiative and strength under these circumstances, and help students to build an extracurricular learning platform so that complete learning opportunities are accessible to students.

Secondly, there might occur conflicts between extracurricular and intracurricular learning. In principle, students' extracurricular learning should be based on inclass learning. But the fact is that some students delay their in-class learning thanks to the hard-earned extracurricular learning chances. Although the specialty of ceramic art is highly practical, it is essential to study theoretical knowledge. Only after learning theoretical knowledge can students understand and grasp the knowledge of ceramic technology, art design, ceramic art history, and so on, and have a framework grasp of ceramic art specialty, so that they can grasp the direction in practice, being more than equal to a task. In fact, extracurricular practical operation separated from theoretical learning is no different from water without a source or from catching fish from a tree, difficult to achieve good learning effect.

\section{Elaboration of ways and means of extracurricular learning for students who major in ceramic art design in universities}

Ministry of Education has already stressed the importance of students' extracurricular learning, required clearly colleges to carry out teaching that combines work with study in relevant documents and put it in an important position to train students' practical ability. Thus, it is the primary task of talent training in the major of ceramic art in colleges to reform talent training mode at present.

The author thinks that the teaching mode that combines work with study is an important platform to provide students with extracurricular learning, and an important supporting theoretical system of the major of ceramic art to carry out talent training and offer extracurricular learning chances. At the same time, local government has made clear commitments and given great support to the improvement of school-running facilities and conditions to open the major, introduction of advanced talents, cooperation of the school with enterprises, and so on, which guarantees the implementation of talent training mode of this major, that is, production blends with learning, the internal with the external. Within the college, a construction committee of ceramic art design specialty is set up, which is made up of ceramic enterprise leaders, technical backbones and statelevel ceramic masters. Its specific work is mainly as follows: To pass relevant bills of the construction committee, and hold a meeting to solve major problems; to implement relevant policies and specific measures of the cooperation of the school with the enterprise, and focus on solving outstanding contradictions and problems in professional development and the cooperation of the school with the enterprise; to optimize major structure, and draw up teaching standards for ceramic art design specialty; to participate in the review of the college's guiding teaching plan and practical training program; to participate in the compilation of standards of teaching factory within the school; to be responsible for discussing the regional industrial development situation, analyzing talent demand, determining the direction of specialty construction, coordinating professional construction, curriculum construction, teacher training and part-time teacher appointment, and to guarantee the talent training mode of this major, that is, production blends with learning, the internal with the external.

On this basis, students who major in ceramic art could get enough extracurricular learning chances with the support of the school, get a chance to put ceramics process into practice step by step outside of the class, and get chances to cultivate themselves into comprehensive professional talents.

\section{Conclusion}

The study of ceramic art major in a college must emphasize the importance of learning in practice. The teaching of ceramic art major in the future is bound to combine in-class learning with extra-curricular learning. Based on the college, it is the inevitable trend of teaching development in future to combine work with learning. There are some disadvantages in university students' exploration of extra-curricular learning chances in ceramic art major by themselves, who need the college to provide the platform and chance for them. Thus, the college should reform teaching pattern, implement the teaching method of unification of production, education and research, provide students with extra-curricular learning chances, so that students can have the chance to put theoretical knowledge they learn into practice.

\section{References}

1. Ding Jinchang. On Further Understanding of Promoting 'School-Enterprise Cooperation and Combination of Work with Learning' in Higher Vocational Education [J]. Higher Education Research, 2008 (6).

2. Chen Jiefang. Choices of Implementation Paths of Talent Training Mode Based on China's National Conditions [J]. China Higher Education Research, 2007 (7).

3. Tian Xiuping. Exploration and Practice of Vocational Collectivization Mode of Running a School [J]. Ceramic Research and Vocational Education, 2008 (4).

4. Zheng Xingwo \& Ma Xiuxian. Practice and Exploration of the Teaching Mode that is Positioned in Binary and Dual Teachers' Teaching System [J]. Industrial Technology and Vocational Education, 2011 (4). 